\title{
ANALISIS KONSUMSI LEMAK, GULA DAN GARAM PENDUDUK INDONESIA
}

\author{
Hardinsyah ${ }^{1}$ \\ ${ }^{1}$ Guru Besar Departemen Gizi Masyarakat, Fakultas Ekologi Manusia (FEMA) IPB \\ Ketua Umum PERGIZI PANGAN Indonesia
}

\section{ABSTRAK}

Studi epidemiologi menunjukkan bahwa asupan lemak yang tinggi, terutama lemak jenuh, gula dan garam adalah faktor risiko terjadinya berat badan lebih, hiperglikemia, hipertensi, dan hiperkolesterol. Studi ini bertujuan untuk menganalisa asupan total lemak, lemak jenuh, gula dan garam pada penduduk Indonesia dari data sekunder SUSENAS. Hasil analisis menunjukkan bahwa rerata asupan lemak adalah 58,1 $\mathrm{g} / \mathrm{kap} / \mathrm{hr}$ tahun 2002 dan meningkat menjadi 61,5 g/kap/hr pada tahun $2007 \mathrm{dan}$ 64,7 g/kap/hr tahun 2009, di mana sekitar setengahnya merupakan lemak nyata dan dua pertiga-nya (62.6\%) merupakan lemak jenuh. Rerata asupan gula nyata 28,3 g/kap/hr pada tahun 2002, 26,2 g/kap/hr tahun 2007 dan $23.8 \mathrm{~g} / \mathrm{kap} / \mathrm{hr}$ tahun 2009. Rerata asupan garam adalah $6,31 \mathrm{~g} / \mathrm{kap} / \mathrm{hr}$ pada tahun 2002, 5,6 g/kap/hr tahun 2007 dan $5.7 \mathrm{~g} / \mathrm{kap} / \mathrm{hr}$ pada tahun 2009. Estimasi yang rendah terjadi pada asupan gula dan garam. Asupan energi dari lemak jenuh dan asupan garam lebih tinggi dari rekomendasi WHO (2003). Asupan energi dari gula sama dengan tambahan asupan gula yang direkomendasi pedoman umum gizi seimbang, tetapi beberapa asupan gula lebih tinggi dari rekomendasi. Strategi kebijakan dan program promosi dalam mengurangi asupan lemak jenuh, gula, dan garam yang terintegrasi dalam promosi gizi seimbang dan pola hidup sehat sangat diperlukan menuju masyarakat Indonesia yang sehat.

Kata kunci: analisis konsumsi, lemak, gula, garam

ABSTRACT

\section{ANALYSIS INTAKE OF FAT, SUGAR AND SALT OF INDONESIANS}

Epidemiological studies show that high intake of fat, especially saturated fat, sugar and salt, are part of risk factors for overweight, hyperglicemia, hypertension and hypercholesterol. This study is aimed to analyze the intake of fat, saturated fat, sugar and salt of Indonesians using secondary data of the Susenas. The results show that the mean intake of fat is $58.1 \mathrm{~g} / \mathrm{cap} / \mathrm{d}$ in 2002 and increased to $61.5 \mathrm{~g} / \mathrm{cap} / \mathrm{d}$ in 2007 and become $64.7 \mathrm{~g} / \mathrm{cap} / \mathrm{d}$ in 2009 , in which about half of it is visible fat, and two-third $(62.6 \%)$ is saturated fat. The mean intake of visible sugar is $28.3 \mathrm{~g} / \mathrm{cap} / \mathrm{d}$ in 2002, $26.2 \mathrm{~g} / \mathrm{cap} / \mathrm{d}$ in 2007 and $23.8 \mathrm{~g} / \mathrm{cap} / \mathrm{d}$ in 2009 , The mean intake of salt is $6.31 \mathrm{~g} / \mathrm{cap} / \mathrm{d}$ in $2002,5.6 \mathrm{~g} / \mathrm{cap} / \mathrm{d}$ in 2007 and $5.7 \mathrm{~g} / \mathrm{cap} / \mathrm{d}$ in 2009 . Both intake of sugar and salt are underestimation. Energy intake from saturated fat and salt intake are higher than recommended initiated by the WHO (2003). Energy intake from sugar is similar to added sugar intake recommendation stated in the Indonesian dietary guidelines, but some had sugar intake higher than the recommendation. Policy, strategies and programs on promoting less intake of saturated fat, sugar and salt, which are integrated into the promotion of balance diet and healthy life style are urgently required to achieve healthier Indonesians.

Keywords: analyze intake, fat, sugar, salt

\section{PENDAHULUAN}

$\mathrm{H}$ ubungan antara faktor pangan dengan kejadian penyakit degeneratif telah banyak dibuktikan. Berbagai komponen pangan, termasuk zat gizi, ada yang bersifat protektif terhadap atau mengurangi risiko penyakit degeneratif. Sebaliknya ada pula berbagai komponen pangan yang meningkatkan berisiko terjadinya penyakit degeneratif terutama melalui peningaktan kejadian hiperglikemia, hipertensi, hiperkolesterol dan penurunan imunitas. ${ }^{1}$ Lebih khusus lagi, berbagai studi epidemiologi telah membuktikan bahwa terdapat hubungan positif yang bermakna antara konsumsi lemak, terutama lemak jenuh, konsumsi gula dan garam dengan kejadian penyakit jantung koroner (WHO, 2003) ${ }^{2}$ dan hubungan konsumsi konsumsi lemak jenuh dan garam dengan hipertensi. ${ }^{1}$

WHO (2003) menganjurkan konsumsi energi dari lemak tidak lebih dari 30 persen. ${ }^{2}$ 
Dalam laporan WHO (2003) dinyatakan bahwa pada masyarakat yang rata-rata konsumsi lemak jenuh di bawah 10 persen konsumsi energi dan serum kolesterol dibawah $200 \mathrm{mg} / \mathrm{dl}$ $(<5.17 \mathrm{mmol} / \mathrm{L}$ ) mengalami angka kematian PJK yang rendah. ${ }^{2}$

Arah pembangunan gizi dan kesehatan Indonesia masa datang tidak hanya pada masalah gizi kurang tetapi juga perlu memberikan perhatian pada masalah gizi lebih (kegemukan) dan berbagai penyakit yang berkaitan dengan hal tersebut. ${ }^{3}$ Makalah ini membahas tentang analisis kecenderungan konsumsi lemak termasuk lemak tidak jenuh, konsumsi gula dan garam penduduk Indonesia, identifikasi permasalahannya dan saran untuk mengatasi permasalahan konsumsi lemak, gula dan garam.

\section{METODE PENELITIAN}

Penelitian ini dilakukan menggunakan data sekunder dari data konsumsi pangan Susenas 2002, 2007 dan 2009.4,5,6 Karena data kompoisisi pangan tentang lemak jenuh tidak tersedia dalam Daftar Komposisi Bahan Makanan Indonesia, maka digunakan kandungan lemak jenuh pangan yang terdapat dalam daftar komposisi bahan makanan untuk Asia, yan terdapat kelemahan karena beberapa komoditas pangan yang ada dalam Susenas tidak terdapat dalam daftar komposisi pangan Asia. Hasil penelitian disajikan dalam bentuk tabel dan dibandingkan dengan dengan data sekunder dari hasil-hasil studi atau laporan terkait dan standar anjuran konsumsi lemak, gula tambahan dan garam oleh WHO (2003). ${ }^{2}$

\section{KONSUMSI LEMAK}

Secara umum lemak dalam pangan dikelompokkan pada lemak jenuh (saturated fat) dan lemak tidak jenuh (unsaturated fat) dan lemak trans (trans fat). Sehingga total kandungan lemak pangan terdiri adalah penjumlahan lemak jenuh, lemak tidak jenuh dan lemak trans. Lemak bermanfaat bagi tubuh untuk menghasilkan energi, menghasilkan asam-asam lemak, pembentukan berbagai komponen lemak darah, dan untuk membentuk cadangan lemak tubuh. Jumlah dan komposisi asupan atau konsumsi lemak akan menentukan jumlah dan komposisi berbagai komponen lemak di dalam darah. Dari segi kekasatan mata, lemak dapat dikategorikan pada lemak tampak (visible fat) dan lemak tidak tampak (invisible fat). Lemak yang padat dan cair termasuk dalam kategori lemak tampak. Lemak yang ada dalam pangan, seperti lemak dalam daging, lemak dalam alpokat, lemak dalam makanan gorengan termasuk dalam kategori lemak tidak tampak.

Hasil analisis terhadap data modul konsumsi Survei Sosial Ekonomi Nasional (Susenas) menunjukkan rata-rata konsumsi lemak total penduduk Indonesia adalah 58,1 $\mathrm{g} / \mathrm{kap} / \mathrm{hr}$ pada tahun $2002^{4}$, meningkat menjadi 61,5 g/kap/hr tahun $2007^{5}$ dan 64,7 g/kap/hr tahun $2009^{6}$ (Tabel 1). Analisis berdasarkan kelompok pengeluaran rumahtangga, menunjukkan bahwa semakin tinggi tingkat ekonomi atau daya beli rumah tangga semakin tinggi konsumsi lemak total. Rata-rata konsumsi lemak total pada kelompok pengeluaran tertinggi tiga kali konsumsi lemak total pada kelompok pengeluaran paling rendah pada Susenas 2009. ${ }^{6}$ Hasil berbagai studi selama 25 tahun terakhir tentang konsumsi lemak total pada contoh wanita dan pria dewasa di Indonesia adalah 23,0-64,6 g/kap/hr dan pada contoh rumah tangga 47,8-61,5 g/kap/hr (Tabel 2).

Data konsumsi lemak (Tabel 1) menunjukkan sekitar separuh konsumsi lemak adalah lemak tampak (visible fat) dan separoh lagi adalah lemak tidak tampak (invisible fat). Lemak tampak ini terutama terdiri dari minyak goreng (terutama minyak sawit), santan kelapa dan mentega yang tinggi kandungan lemak jenuh. 
Tabel 1

Konsumsi Lemak Total dan Lemak Tampak Tahun 2002, 2005 dan 2009

\begin{tabular}{ccc}
\hline Tahun & $\begin{array}{c}\text { Konsumsi lemak total (visible dan } \\
\text { invisible fat) } \\
\text { (g/kap/hr) }\end{array}$ & $\begin{array}{c}\text { Konsumsi lemak tampak } \\
\text { (visible fat) } \\
\text { (g/kap/hr) }\end{array}$ \\
\hline 2002 & 58,1 & 30,6 \\
2007 & 61,5 & 30,1 \\
2009 & 64,7 & 29,7 \\
\hline
\end{tabular}

Sumber: Diolah dari SUSENAS 2002, 2007 dan 2009

Rata-rata konsumsi lemak jenuh adalah $38,1 \mathrm{~g} / \mathrm{kap} / \mathrm{hr}$, yaitu sekitar dua-pertiga $(61,9 \%)$ dari lemak yang dikonsumsi. Jumlah konsumsi lemak jenuh tersebut setara dengan sekitar 342,9 kkal atau 17,2 persen energi. Meskipun konsumsi lemak total relatif sama antar wilayah kota dan desa, tetapi proporsi konsumsi lemak jenuh di wilayah desa sedikit lebih tinggi dibanding di wilayah kota (Tabel 3).

Tabel 2

Review Konsumsi Lemak Total dari Berbagai Studi di Indonesia

\begin{tabular}{clll}
\hline $\begin{array}{c}\text { Konsumsi Lemak } \\
(\mathrm{g} / \mathrm{kap} / \mathrm{hr})\end{array}$ & \multicolumn{1}{c}{ Sample (Contoh) } & \multicolumn{1}{c}{ Metode } & \multicolumn{1}{c}{ Sumber } \\
\hline 61,5 & 60.000 rumah tangga & 7-day food recall & Diolah dari Susenas, 20075 \\
$38,6-64,6$ & Pria dan wanita dewasa dari 4 etnik & Semi-FFQ & Juwita, R (2007) \\
52,9 & 100 ibu hamil di Jakarta & Semi-FFQ, 1 minggu & Hardinsyah \& Mulyani $(2008)^{8}$ \\
47,8 & 17117 rumahtangga & 7-day food recall & Hardinsyah, 19969 \\
23,0 & 89 pria dewasa di Sumbar & 24-hr food recall & Malik dkk, 1989 dalam Hardinsyah (1996) \\
45,0 & 52 pria dewasa kota di Sumbar & 3-day food recall & Oenzil, 1982 dalam Hardinsyah $(1996)^{9}$ \\
34,0 & 50 pria dewasa desa di Sumbar & 3-day food recall & Oenzil, 1982 dalam Hardinsyah $(1996)^{9}$ \\
\hline
\end{tabular}

Tabel 3

Konsumsi lemak total dan lemak jenuh menurut wilayah tahun 2009

\begin{tabular}{lcrrrrr}
\hline Wilayah & $\begin{array}{c}\text { Lemak } \\
(\mathrm{g} / \mathrm{kap} / \mathrm{hr})\end{array}$ & $\begin{array}{c}\text { Lemak } \\
\text { tampak } \\
(\mathrm{g} / \mathrm{kap} / \mathrm{hr})\end{array}$ & $\begin{array}{c}\text { Lemak jenuh } \\
(\mathrm{g} / \mathrm{kap} / \mathrm{hr})\end{array}$ & $\begin{array}{c}\text { Proporsi } \\
\text { lemak jenuh } \\
(\%)\end{array}$ & $\begin{array}{c}\text { Persen } \\
\text { energi dari } \\
\text { lemak total } \\
(\%)\end{array}$ & $\begin{array}{c}\text { Persen energi } \\
\text { dari lemak } \\
\text { jenuh }(\%)\end{array}$ \\
\hline Kota & 63,4 & 28,7 & 38,2 & 60,3 & 28,5 & 17,2 \\
Desa & 65,5 & 30,3 & 41,8 & 63,8 & 29,5 & 18,8 \\
K+D & 64,7 & 29,7 & 40,5 & 62,6 & 29,1 & 18,2 \\
\hline \multicolumn{4}{l}{ Sumber: Diolah dari SUSENAS 20096 } & & &
\end{tabular}

WHO (2003) menganjurkan konsumsi lemak 15-30 persen total konsumsi energi, tergantung tahap tumbuh kembang (umur), jenis kelamin dan pertimbangan lainnya. ${ }^{2}$ Dalam berbagai pesan pedoman gizi (dietary guidelines) di berbagai negara maju dianjurkan konsumsi lemak kurang dari 30 persen energi; dan dalam pesan Pedoman Umum Gizi Seimbang (PUGS) Indonesia dianjurkan konsumsi lemak tidak lebih dari 25 persen 
energi. ${ }^{10} \mathrm{Hal}$ ini berarti, anjuran maksimal kebutuhan lemak perkapita perhari bagi penduduk Indonesia dengan rata-rata kebutuhan energi $2000 \mathrm{kkal} / \mathrm{hari}$ adalah 500 kkal energi dari lemak atau tidak lebih dari $56 \mathrm{~g}$ lemak perkapita perhari.

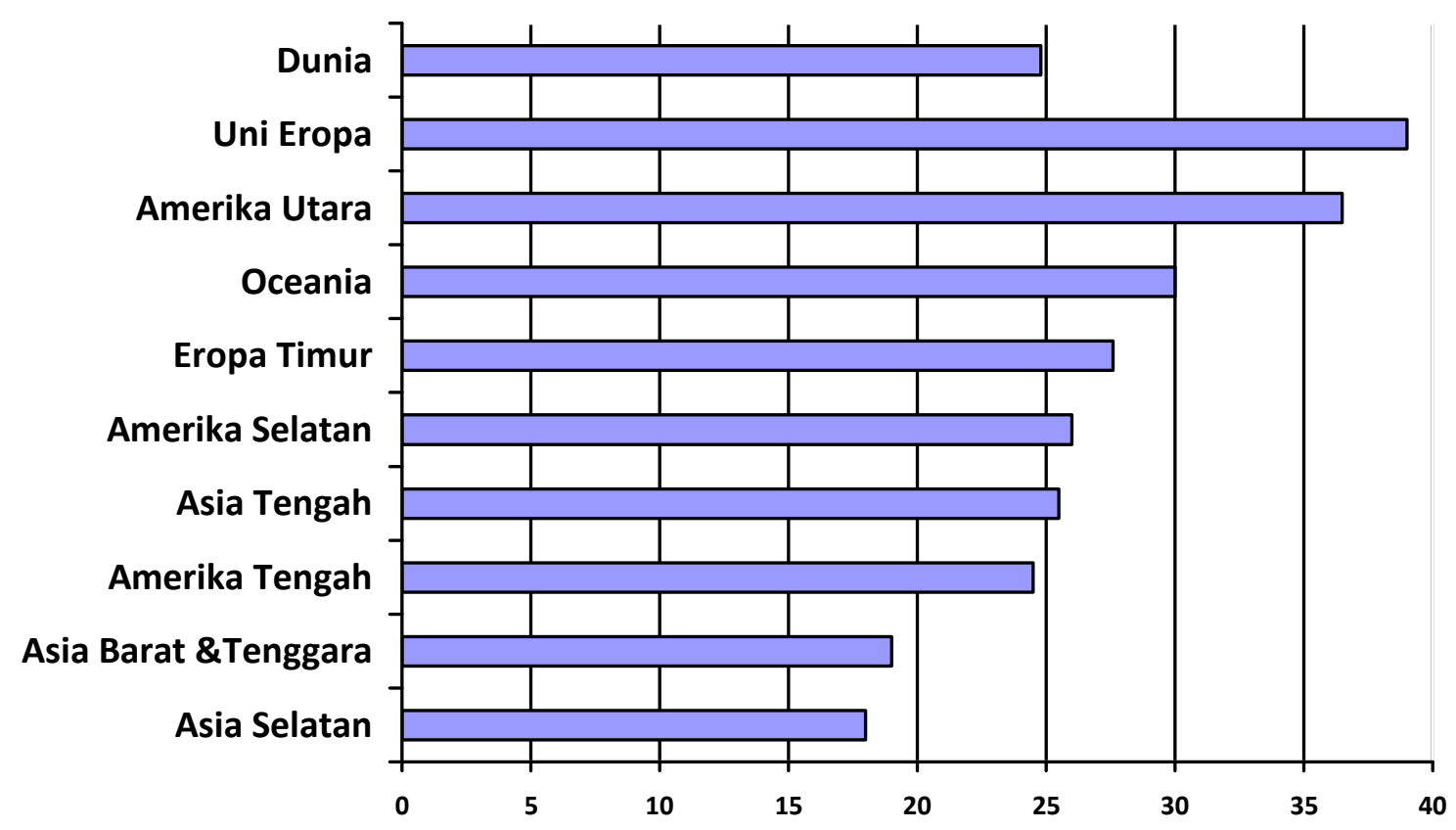

Gambar 1

Persentase Konsumsi Energi dari Lemak di Dunia dan Berbagai Kawasan (WHO, 2003)²

Persentase konsumsi energi dari lemak jenuh ini $(18,2 \%)$ jauh melebihi anjuran konsumsi lemak jenuh oleh WHO (2003), yaitu kurang dari 10 persen energi. ${ }^{2}$ Hal ini menunjukkan bahwa meskipun konsumsi lemak total penduduk Indonesia mendekati batas ambang anjuran maksimal oleh WHO (2003), tetapi proporsi lemak jenuh tergolong tinggi, yang meningkatkan risiko penyakit kronik degeneratif. Fakta ini bisa menjadi salah satu penjelas kenapa di beberapa negara asia yang asupan total lemaknya jauh di bawah 30 persen energi tetapi kejadian penyakit jantung koroner semakin meningkat. Pada Gambar 1 ditunjukkan bahwa di negara-negara Asia Tenggara dan Timur, Asia Selatan dan Afrika pada umumnya persentase energi dari lemaknya jauh di bawah 20 persen energi. Sementara konsumsi lemak di negara-negara Eropa, Amerika Utara (USA dan Canada) dan Oceania terjadi sebaliknya, yaitu di atas 35 persen energi.

\section{KONSUMSI GULA}

Gula dalam konteks ini salah satu jenis pangan karbohidrat yang dalam kesaharian disebut gula putih (gula pasir) dan gula merah yang merupakan sukrosa. Sukrosa oleh tubuh dipecah menjadi glukosa dan fruktosa. Kelebihan karbohidrat ini akan disimpan dalam bentuk glikogen dan lemak; dan glukosa darah yang tinggi menjadi salah satu faktor risiko diabetes tipe 2. Gula putih atau gula merah ditambahkan pada makanan dan minuman untuk citarasa, pengawet dan meningkatkan kandungan energi makanan dan minuman. Selain dari gula putih dan gula merah, sukrosa juga terkandung dalam buah. Berbeda dengan mengkonsumsi gula, mengkonsumsi buah tidak hanya memperoleh gula sukrosa tetapi juga memperoleh vitamin, mineral, serat, dan flavonoid yang lebih lambat dimetabolisme oleh tubuh. 
Hasil olah data konsumsi Susenas menunjukkan bahwa rata-rata konsumsi gula (gula putih dan gula merah) penduduk Indonesia pada tahun 2002, 2007 dan 2009 berturut-turut adalah adalah 28,3; 26,2 dan 23,8 g/kap/hr.4,5,6 Data konsumsi gula tahun 2009 setara dengan $8,7 \mathrm{~kg} / \mathrm{kap} / \mathrm{thn}$. Data ini adalah data konsumsi gula yang tampak atau visible sugar (Tabel 4).

Tabel 4

Konsumsi gula (visible sugar)pendudk Indonesia tahun 2002, 2007 dan 2009

\begin{tabular}{lcccc}
\hline Wilayah & $\begin{array}{c}2002 \\
(\mathrm{~g} / \mathrm{kap} / \mathrm{hr})\end{array}$ & $\begin{array}{c}2007 \\
(\mathrm{~g} / \mathrm{kap} / \mathrm{hr})\end{array}$ & $\begin{array}{c}2009 \\
(\mathrm{~g} / \mathrm{kap} / \mathrm{hr})\end{array}$ & $\begin{array}{c}\text { Proporsi Energi } \\
\text { dari gula, 2009 } \\
(\%)\end{array}$ \\
\hline Kota & 28,9 & 26,1 & 22,8 & 4,6 \\
Desa & 27,8 & 27,1 & 24,8 & 5,0 \\
K+D & 28,3 & 26,2 & 23,8 & 4,8 \\
\hline
\end{tabular}

Diolah Hardinsyah diolah dari SUSENAS 2002, 2007 dan 2009

Data dari Laporan USDA (2004) bahwa konsumsi gula penduduk Indonesia adalah 3,45 juta ton per tahun (Tabel 5) atau setara dengan $15,6 \mathrm{~kg} / \mathrm{kap} / \mathrm{thn}$ atau $43 \mathrm{~g} / \mathrm{kap} / \mathrm{hr}$, yang berarti mempunyai kontribusi 8,6 persen terhadap total kebutuhan energi $2000 \mathrm{kkal} / \mathrm{kap} / \mathrm{hr}$. Konsumsi gula penduduk Indonesia berdasarkan data konsumsi Susenas 2009 lebih rendah dibanding data konsumsi yang dilaporkan USDA (2004), karena dalam data USDA (2004) termasuk konsumsi gula untuk sirup dan gula yang ditambahkan pada makanan dan minuman produk industri. Secara rasional data konsumsi gula penduduk berdasarkan USDA (2004) lebih akurat.6,11

Dalam Penjelasan Pesan ketiga Pedoman Umum Gizi Seimbang (PUGS) ${ }^{10}$ disebutkan konsumsi gula tambahan (visible sugar) dibatasi sampai 5 persen kecukupan energi. Demikian pula dalam Pola Pangan Harapan (PPH) direkomendasikan konsumsi gula dibatasi sampai 5 persen energi. ${ }^{12}$ Hal ini berarti konsumsi gula penduduk Indonesia tahun 2009 di pedesaan (Tabel 4) yang didasarkan pada data Susenas telah mencapai batas anjuran PUGS dan PPH. Namun bila dihitung dengan tambahan gula dan sirup berdasarkan data USFDA maka rata-rata kontribusi gula tambahan adalah 8,6 persen yang melebihi anjuran dalam PUGS tetapi masih di bawah batas WHO (2003) yang menganjurkan kontribusi energi dari gula tambahan tidak lebih dari 10 persen energi. ${ }^{2}$
Konsumsi gula dikalangan penduduk desa jauh lebih tinggi dibanding di kota, terutama dikalangan kelompok ekonomi menengah ke atas. Analisis berdasarkan tingkat ekonomi rumah tangga (pengeluaran rumah tangga), semakin tinggi tingkat ekonomi rumah tangga semakin meningkat konsumsi gula. Konsumsi gula pada rumah tangga ekonomi tinggi hampir tiga kali konsumsi gula ekonomi rumah tangga rendah pada data Susenas 2009.

Diperkirakan kebutuhan gula nasional akan terus meningkat, terutama karena laju pertumbuhan konsumsi gula secara tidak langsung dari semakin banyaknya produkproduk pangan (makanan dan minuman) yang ditambahkan gula. Bila saat ini konsumsi gula sekitar 4 juta ton sementara kapasitas produksi gula nasional saat ini hanya 1,9 juta ton dan lahan bagi perkebunan tebu semakin terbatas, maka impor gula akan semakin meningkat. Peningkatan konsumsi gula akan meningkatkan ketergantungan bangsa Indonesia pada gula impor selain meningkatkan risiko pada kegemukan dan penyakit terkait seperti hiperglikemia. Artinya peningkatan konsumsi gula tidak baik secara sosial ekonomi, yaitu disamping meningkatkan risiko penyakit juga menurunkan ketahanan pangan. Oleh karena itu baik dari segi kedaulatan pangan, maupun dari segi ekonomi dan kesehatan promosi membatasi konsumsi gula menajdi semakin penting dilakukan bagi Indonesia. 
Tabel 5

Perkembangan Konsumsi Gula di Beberapa Negara termasuk Indonesia 2001-2004 (Juta Ton)

\begin{tabular}{lrrrr}
\hline Negara & $2001 / 2002$ & $2002 / 2003$ & $2003 / 2004$ & $\begin{array}{r}\text { Pertumbuhan } \\
2003 / 2004(\%)\end{array}$ \\
\hline India & 19,760 & 20,750 & 21,500 & 3,61 \\
Eropa Timur & 15,014 & 14,868 & 14,507 & $-2,43$ \\
Uni Eropa (EU) & 14,332 & 14,458 & 14,529 & 0,49 \\
Brazil & 9,450 & 9,640 & 9,980 & 3,53 \\
Amerika Serikat & 9,249 & 8,699 & 9,117 & 4,81 \\
China & 9,050 & 9,122 & 9,194 & 0,79 \\
Mexico & 5,082 & 5,266 & 5,283 & 0,32 \\
Pakistan & 3,450 & 3,500 & 3,500 & 0,00 \\
Indonesia & 3,350 & 3,400 & 3,450 & 1,47 \\
Jepang & 2,277 & 2,314 & 2,250 & $-2,77$ \\
\hline Total Dunia & 134,920 & 136,550 & 138,569 & 1,48 \\
\hline Sumber: USDA: Sugar Market and Trade $(2004)^{11}$ & & &
\end{tabular}

\section{KONSUMSI GARAM}

Berdasarkan hasil olah data ini rata-rata konsumsi garam penduduk adalah 6,$3 ; 5,6$ dan $5,7 \mathrm{~g} / \mathrm{kap} / \mathrm{hr}$ masing masing pada tahun 2002, 2007 dan 2009 (Tabel 6). Tampaknya tidak ada peningkatan konsumsi garam visible salt yang digunakan langsung di rumah tangga. Konsumsi garam menggunakan data ini diperkirakan underestimate karena belum termasuk garam visible salt yang dibubuhkan pada makanan jajanan (bakso, soto, mie goreng dan makanan jajanan lainnya) dan garam visible salt yang dibubuhi pada makanan pabrik atau produk industri. Sementara konsumsi makanan jajanan dan pabrik yang bergaram cenderung semakin tinggi selama satu dekade terakhir. Jadi meskipun angka pada Tabel 6 menunjukkan tidak ada peningaktan konsumsi garam, data ini diduga kuat underestimate.

Tabel 6

Konsumsi Garam (Visible Salt) Tahun 2002, 2007 dan 2009

\begin{tabular}{lccc}
\hline \hline Wilayah & 2002 & 2007 & 2009 \\
\hline Kota & 5,8 & 5,0 & 5,2 \\
Desa & 6,7 & 6,2 & 6,2 \\
K+D & 6,3 & 5,6 & 5,7 \\
\hline Diolah dari SUSENAS 2002, 2007 dan 20094,5,6 & &
\end{tabular}

Garam mensuplai natrium. Anjuran kebutuhan natrium bagi remaja dan dewasa $1200 \mathrm{mg} / \mathrm{hr}$ dan ditolerir (UL) sampai 2300 $\mathrm{mg} / \mathrm{hr}$. Natrium bukanlah hanya dari garam saja.
Natrium diperoleh dari garam, BTP (bahan tambahan pangan) dan natrium dari makanan dan minuman. Dalam bentuk garam, WHO $(2003)^{2}$ menganjurkan konsumsi garam kurang 
dari $5 \mathrm{~g} / \mathrm{kap} / \mathrm{hr}$ untuk hidup sehat. Ini menunjukkan bahwa konsumsi garam penduduk Indonesia sudah melebihi anjuran WHO (2003). ${ }^{2}$ Dalam kaitannya dengan program garam beriodium, dalam jangka panjang akan ada konflik pogram ini dengan program promosi yang membatasi konsumsi garam. Konsumsi garam juga dipromosikan karena kebijakan universal garam beriodium terkait pencegahan GAKI. Pesan 5 PUGS "Gunakanlah Garam Beriodium", dengan anjuran tidak lebih 6 gram $/$ hari. ${ }^{10}$ Anjuran konsumsi garam dalam PUGS ini perlu dikaji ulang disinkronkan dengan anjuran WHO $(2003)^{2}$ dan kondisi Indonesia, di mana kejadian hipertensi semakin meningkat.

Konsumsi garam yang tak tampak cenderung meningkat melalui makanan olahan yang dibumbuhi garam, pengawet dan perasa, serta minuman bernatrium. Sampai saat ini belum ada penelitian konsumsi garam dan natrium yang komprehensif di Indonesia mencakup visible dan non-visible salt dari total diet. Salah satu sebabnya karena Daftar Komposisi Bahan Makanan (DKBM) Indonesia belum menyediakan data kandungan natrium dari setiap pangan olah dan tidak diolah.

\section{IMPLIKASI}

Berdasarkan paparan tersebut di atas tampak bahwa ada masalah tingginya konsumsi lemak, terutama lemak jenuh, dan indikasi tingginya konsumsi gula dan garam terutama pada rumahtangga ekonomi menengah dan atas. Selain itu juga tampak rendahnya konsumsi sayur dan buah serta pangan hewani (Tabel 7). Rata-rata konsumsi buah dan sayur penduduk Indonesia baru sekitar 200,4 g/kap/hr (Tabel 7), yang seharusnya 400/g/kap/hr untuk hidup sehat. Seharusnya porsi buah lebih banyak dibanding porsi sayur karena mempertimbangkan kebiasaan mengolah sayur (dimasak dengan susu tinggi dan banyak kuah) di Indonesia yang memungkinkan banyak vitamin yang hilang. Kenyataan yang ada saat ini porsi sayur lebih banyak.

Demikian pula konsumsi pangan hewani masih jauh dari harapan. Konsumsi pangan hewani saat ini 74,9 g/kap/hr (Tabel 7) yang seharusnya berdasarkan Pola Pangan Harapan, yaitu sebesar $150 \mathrm{~g} / \mathrm{kap} / \mathrm{hr}$.

Tabel 7

Pola Konsumsi Pangan Penduduk Indonesia 2009

\begin{tabular}{|c|c|}
\hline Golongan pangan & Konsumsi (g/kap/hr) \\
\hline Serealia & 330,0 \\
\hline Umbi-umbian & 49,5 \\
\hline Pangan hewani & 74,9 \\
\hline Minyak dan lemak & 29,8 \\
\hline Kacang-kacangan & 19,4 \\
\hline Gula & 24,8 \\
\hline Sayur dan buah & 200,4 \\
\hline Lainnya & 46,5 \\
\hline
\end{tabular}

Diolah Hardinsyah dari SUSENAS $2009^{6}$

Strategi promosi untuk mengatasi masalah ini haruslah disusun dalam satu strategi besar secara menyeluruh dalam konteks promosi Gizi Seimbang (GS) untuk hidup sehat, cerdas, aktif dan produktif, bahkan dalam konteks yang lebih besar lagi yaitu dalam kerangka mewujudkan Pola Hidup Bersih dan Sehat (PHBS). Kebijakan yang mendasari strategi ini perlu dirumuskan, termasuk kebijakan dan program lintas sektor tentang hal ini agar promosi pola makan rendah lemak, gula dan garam sejalan dengan insentif dan disinsentif bagi dunia industri dalam pengembangan produk (termasuk jajanan dan snack) yang rendah lemak, gula dan garam. Demikian pula dengan insentif bagi peningkatan penyediaan, pemasaran/perdagangan aneka produk buah dan sayur.

Dari segi komunikasi, berbagai kegiatan promosi makan sehat oleh instansi pemerintah 
selama ini masih terbatas pada upaya-upaya klasik melalui media cetak dan penyuluhan serta kurang menarik dan menyenangkan. Kelemahan ini perlu diperbaiki dengan strategi baru seperti layaknya dilakukan oleh swasta atau industri pangan. Oleh karena itu dimasa datang diperlukan suatu strategi promosi gizi seimbang yang rendah lemak jenuh, gula dan garam, termasuk peningkatan konsumsi buah dan sayur serta pangan hewani, baik di desa mapun kota melalui pesan-pesan sederhana yang menarik dan menyenangkan dengan pendekatan multi-media yang tepat secara berkelanjutan.

Tantangan lainnya yang sekaligus bisa menjadi peluang bila dikelola dengan kebijakan yang baik adalah peran dunia industri pangan dan media massa. Selama ini industri pangan dan media massa lebih banyak mempromosikan pangan yang tinggi lemak, gula dan sodium. Perlu ada kebijakan dan program yang memberikan insentif bagi dunia industri pangan (swasta) yang mengembangkan produk dan mempromosikan pangan rendah lemak jenuh, rendah gula dan rendah garam, misalnya melalui instrumen harga, pajak dan labeling.

Gizi telah diakui menjadi bagian penting dalam pembangunan baik dalam pembangunan sosial maupun pembangunan ekonomi. ${ }^{13}$ Oleh karena itu upaya perbaikan gizi dalam pembangunan secara keseluruhan haruslah dikaitkan dengan perubahan perilaku gizi. Promosi perubahan perilaku memerlukan waktu panjang dan perlu berkesinambungan, serta akan lebih baik bila diintegrasikan dengan strategi promosi gizi seimbang dan pola hidup bersih dan sehat (PHBS) sejak usia dini dengan pendekatan berbasis keluarga, masyarakat, sekolah dan kelembagaan lainnya. Kebijakan dan program promosi yang baik menghendaki ketenagaan, sumberdaya dan kelembagaan, kepemimpinan, kemitraan dan koordinasi yang tangguh yang tangguh.

\section{SIMPULAN DAN SARAN}

\section{Simpulan}

1. Rata-rata konsumsi lemak penduduk meningkat dari tahun 2002 ke 2009. Ratarata konsumsi lemak 58,1 $\mathrm{g} / \mathrm{kap} / \mathrm{hr}$ pada tahun 2002; 61,5 g/kap/hr tahun 2007 dan
$64,7 \mathrm{~g} / \mathrm{kap} / \mathrm{hr}$ tahun 2009. Rata-rata proporsi energi dari lemak adalah 29,1 persen yang melebihi anjuran Depkes (2004) dalam Pedoman Gizi Seimbang (PUGS) yaitu tidak lebih dari 25 persen energi.

2. Sekitar separuh konsumsi lemak adalah lemak tampak (visible fat) yang tinggi kandungan lemak jenuh. Rata-rata proporsi konsumsi lemak jenuh dalam konsumsi lemak total adalah 62,6 persen, dan proporsi energi dari lemak jenuh terhadap total energi adalah 18,2 persen yang jauh melebihi anjuran WHO (2003) yang seharusnya kurang dari 10 persen.

3. Rata-rata konsumsi gula yang tampak (visible sugar) penduduk Indonesia 28,3 $\mathrm{g} / \mathrm{kap} / \mathrm{hr}$ atau setara 4,8 persen total energi. Rata-rata konsumsi garam (visible salt) penduduk 5,7 g/kap/hr. Angka konsumsi gula dan garam ini diperkirakan underestimate karena belum termasuk gula dan garam yang ditambahkan pada makanan jajanan, sementara konsumsi makanan jajanan dan pabrik yang ditambahkan gula dan garam cenderung semakin meningkat.

4. Semakin tinggi tingkat ekonomi rumahtangga semakin tinggi konsumsi lemak, gula dan garam. Rata-rata konsumsi lemak dan gula pada kelompok pengeluaran tinggi sekitar 3 (tiga) kali konsumsi lemak dan gula kelompok pengeluaran paling rendah.

\section{Saran}

1. Peningkatan konsumsi gula dan garam akan meningkatkan ketergantungan bangsa Indonesia pada gula dan garam impor selain meningkatkan risiko pada berbagai penyakit terkait. Oleh karena itu baik dari segi kedaulatan pangan, maupun dari segi ekonomi dan kesehatan promosi membatasi konsumsi gula menjadi semakin penting dilakukan bagi Indonesia.

2. Mempertimbangkan hasil kajian epidemiologis bahwa konsumsi lemak, gula dan galam merupakan bagian dari faktor risiko penyakit kronik degeneratif, maka diperlukan suatu strategi promosi pola konsumsi pangan rendah lemak (terutama lemak jenuh), rendah gula dan rendah 
garam dalam konteks gizi seimbang dan Pola Hidup Bersih dan Sehat (PHBS).

3. Lebih khusus lagi dalam jangka pendek promosi tersebut ditujukan terutama bagi penduduk golongan ekonomi menengah $\mathrm{ke}$ atas baik di desa mapun kota melalui pesan-pesan sederhana yang menarik dan menyenangkan dengan media yang tepat melalui kelembagaan yang ada secara berkelanjutan. Dalam jangka panjang ditujukan kepada anak sejak usia dini melalui pendekatan keluarga, masyarakat dan sekolah.

4. Diperlukan kajian untuk pengembangan daftar komposisi bahan makanan (DKBM) pangan Indonesia, baik pangan olahan maupun mentah agar mencakup kandungan asam-asam lemak terutama lemak jenuh dan trans, kandungan kolesterol, kandungan beragam karbohidrat, terutama gula (glukosa dan sukrosa), dan kandungan sodium.

\section{RUJUKAN}

1. Agrawal VK, Bhalwar R, Basannar DR. Prevalence and Determinants of Hypertension in a Rural Community. MJAFI, 2008;64:21-25.

2. World Health Organization (WHO). Diet and Chronic Diseases. Geneva: World Health Organization, 2003.

3. Badan Perencanaan Pembangunan Nasional (Bappenas). Pembangunan Kesehatan dan Gizi di Indonesia: Overview dan Arah ke Depan. Jakarta: Bappenas, 2009.

4. Badan Pusat Statistik. Konsumsi Pangan Penduduk Indonesia, SUSENAS 2002. Jakarta: Badan Pusat Statistik, 2003.
5. Badan Pusat Statistik (BPS). Konsumsi Pangan Penduduk Indonesia, SUSENAS 2007. Jakarta:Badan Pusat Statistik, 2008.

6. Badan Pusat Statistik. Konsumsi Pangan Penduduk Indonesia, SUSENAS 2009. Jakarta: Badan Pusat Statistik, 2010.

7. Djuwita, R. Studi cross sectional mengenai asupan gizi pada empat etnik di Indonesia (Minangkabau, Sunda, Jawa dan Bugis). Depok: FKM UI, 2007.

8. Hardinsyah dan Mulyani. Konsumsi Gizi Ibu Hamil di Jakarta Timur dan Jakarta Selatan. Departemen Gizi Masyarakat dan Sumberdaya Keluarga. Bogor: Fakultas Pertanian IPB, 2008.

9. Hardinsyah. Measurement and Determinants of Food Diversity: Implications for Food and Nutrition Policies. Disertation. Brisbane: University of Queensland, 1996.

10. Departemern Kesehatan (Depkes). Pedoman Umum Gizi Seimbang (PUGS). Jakarta: Depkes, 2004.

11. United States, Department of Agriculture (USFDA). Sugar Market and Trade. Washington, DC: United States, Department of Agriculture, 2004.

12. Hardinsyah, Baliwati, Y., Martianto, D., Rachman, HS., Widodo, A. Subiyakto. Pengembangan Konsumsi Pangan dengan Pendekatan Pola Pangan Harapan. Jakarta: Pusat Studi Kebijakan Pangan dan Gizi (PSKPG) LP IPB dan Pusat Pengembangan Konsumsi Pangan Badan Bimas Ketahanan Pangan Deptan, 2001.

13. World Bank. Reposition Nutrition as Central in Development. Washington DC: World Bank, 2006. 